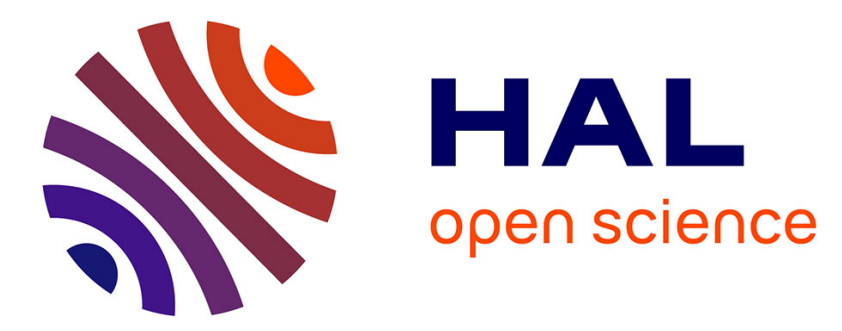

\title{
Validation and characterisation of the Sweeping Langmuir Probe (SLP) instrument for the PICASSO mission
}

Sylvain Ranvier, Michel Anciaux, Jean-Pierre Lebreton, Johan de Keyser

\section{- To cite this version:}

Sylvain Ranvier, Michel Anciaux, Jean-Pierre Lebreton, Johan de Keyser. Validation and characterisation of the Sweeping Langmuir Probe (SLP) instrument for the PICASSO mission. 22nd EGU General Assembly, 2020, Online, France. 10.5194/egusphere-egu2020-14126 . insu-03560751

\section{HAL Id: insu-03560751 \\ https://hal-insu.archives-ouvertes.fr/insu-03560751}

Submitted on 8 Feb 2022

HAL is a multi-disciplinary open access archive for the deposit and dissemination of scientific research documents, whether they are published or not. The documents may come from teaching and research institutions in France or abroad, or from public or private research centers.
L'archive ouverte pluridisciplinaire HAL, est destinée au dépôt et à la diffusion de documents scientifiques de niveau recherche, publiés ou non, émanant des établissements d'enseignement et de recherche français ou étrangers, des laboratoires publics ou privés.

\section{(ㄷ)(1)}

Distributed under a Creative Commons Attribution| 4.0 International License 
EGU2020-14126

https://doi.org/10.5194/egusphere-egu2020-14126

EGU General Assembly 2020

(c) Author(s) 2022. This work is distributed under

the Creative Commons Attribution 4.0 License.

\title{
Validation and characterisation of the Sweeping Langmuir Probe (SLP) instrument for the PICASSO mission
}

\author{
Sylvain Ranvier ${ }^{1}$, Michel Anciaux ${ }^{1}$, Jean-Pierre Lebreton ${ }^{2,3}$, and Johan De Keyser ${ }^{1}$ \\ ${ }^{1}$ Royal Belgian Institute for Space Aeronomy, Space Physics, Brussels, Belgium (sylvain.ranvier@aeronomie.be) \\ ${ }^{2}$ Laboratoire de Physique et Chimie de l'Environnement et de l'Espace (LPC2E), Orléans, France \\ ${ }^{3}$ Laboratoire d'Etudes Spatiales et d'Instrumentation en Astrophysique (LESIA), Meudon, France
}

The Sweeping Langmuir Probe (SLP) instrument, that uses a novel measurement technique to take into account spacecraft charging effects, has been developed at the Royal Belgian Institute for Space Aeronomy. SLP will fly on board the ESA scientific in-orbit demonstrator PICASSO together with the hyper-spectral imager VISION. PICASSO, a triple unit CubeSat, will be launched in March 2020. The goal of the mission is to prove the feasibility of performing true science (with limited extent) with a nano-satellite and demonstrate the very low cost / science ratio with respect to big missions. SLP will allow a global monitoring of the ionosphere with a maximum spatial resolution of the order of $150 \mathrm{~m}$. The main goals are to study the ionosphere-plasmasphere coupling, the subauroral ionosphere and corresponding magnetospheric features together with auroral structures and polar caps, by combining SLP data with other complementary data sources (spaceor ground-based instruments). SLP can measure plasma density from $1 \mathrm{e} 8 / \mathrm{m}^{3}$ up to $1 \mathrm{e} 13 / \mathrm{m}^{3}$ and electron temperature up to $15000 \mathrm{~K}$.

We will present the main results from the validation tests performed in the plasma chamber at ESTEC together with comparisons with particle-in-cell (PIC) simulations performed with SPIS (Spacecraft Plasma Interaction System). 